\title{
SISTEM INFORMASI LAYANAN DIGITAL PUSKESMAS BERBASIS ANDROID
}

\author{
Hasan Basri ${ }^{1)}$, Dedin Toyibah ${ }^{2)}$, Muhamad Fakhri ${ }^{3)}$, Hanafi Dirgantara Musahar ${ }^{4)}$, \\ Wina Wati 5), Riski Nur Idad 6), Widya Apriliah 7) \\ 1,2,3,4,5,6,7 Teknik dan Informatika, Universitas Bina Sarana Informatika PSDKU Karawang, Jl. Banten No. 1 \\ Karangpawitan Karawang, Telp (0267) 8454893 \\ email: hasan.hhi@bsi.ac.id ${ }^{1}$, dedinarc70@gmail.com ${ }^{2}$,mfakhri0797@gmail.com ${ }^{3}$, \\ hanafidirgantara4@gmail.com ${ }^{4}$,winawati2908@gmail.com ${ }^{5}$, itsme.riskynuridad@gmail.com ${ }^{6}$, \\ widya.wyr@,bsi.ac.id ${ }^{7}$
}

\begin{abstract}
Abstrak
Perkembangan teknologi informasi yang sangat cepat terbukti berperan penting dalam perkembangan percepatan informasi baik dalam dunia industri, pemerintahan, dan dunia kesehatan, sehingga dapat mendukung kinerja peningkatan efisiensi, efektivitas dan produktivitas semua lapisan elemem masyarakat, khususnya di dunia kesehatan, baik instansi pemerintahan negeri, swasta maupun perorangan atau individual, yang dapat mendorong perwujudan masyarakat yang maju dan sejahtera. Sektor kesehatan merupakan salah satu sektor penting dari pembangunan yang sangat potensial untuk dapat diintegrasikan dengan kehadiran teknologi. Puskesmas Bayur Lor Kec. Cilamaya Kulon Kabupaten Karawang menjadi salah satu pusat pelayanan kesehatan yang sedang berkembang. Jumlah pasien yang terus meningkat setiap harinya menyebabkan masalah baru dalam proses pencarian informasi tentang pasien, jumlah pasien, jumlah kunjungan, total pendapatan, dan data persediaan obat yang ada. Oleh karena berdasarkan permasalahan yang ada, maka Puskesmas Bayur Lor Kec. Cilamaya Kulon Kabupaten Karawang, perlu memanfaatkan teknologi informasi, yang dapat mengatasi masalah-masalah yang dihadapi, sehingga pelayanan kesehatan masyarakat dapat meningkat demi terwujudnya visi dan misi puskesmas bayur lor kec. Cilamaya Kulon. Melihat dari beberapa permasalahan yang ada, peneliti menggunakan metode waterfall dalam pembuatan sebuah sistem informasi. Aplikasi yang dibuat pada penelitian ini adalah berbasis android. Untuk memudahkan dalam penyebutan aplikasi ini yaitu LAGILEMAS (Layanan Digital Puskesmas) Berbasis Android. Hasil capaian yang diperoleh dari pemanfaatan LAGILEMAS (Layanan Digital Puskesmas) Berbasis Android yaitu membantu proses administrasi pada puskesmas bayur lor kec. Cilamaya Kulon, Kabupaten Karawang, proses antrian peserta dapat berjalan dengan kondusif, peserta atau pasien datang sesuai jadwal dokter yang terdapat pada aplikasi, data obat terorganisir dengan baik, laporan pendapatan atau laporan keuangan dapat dilihat secara up to date.

Kata kunci : Puskesmas, Waterfall, Aplikasi Android
\end{abstract}




\begin{abstract}
The very rapid development of information technology has proven to play an important role in the accelerated development of information both in the world of industry, government and the world of health, so that it can support the performance of increasing the efficiency, effectiveness and productivity of all elements of society, especially in the world of health, both public and private institutions. or individually or individually, which can encourage the realization of a developed and prosperous society. The health sector is one of the important sectors of development that has the potential to be integrated with the presence of technology. Public health center Bayur Lor. Cilamaya Kulon, Karawang Regency is one of the developing health service centers. The number of patients that continues to increase every day causes new problems in the process of seeking information about patients, the number of patients, the number of visits, total income, and data on existing drug supplies. Because based on the existing problems, the Public health center Bayur Lor. Cilamaya Kulon, Karawang Regency, needs to take advantage of information technology, which can overcome the problems faced, so that public health services can be improved for the realization of the vision and mission of the Public health center Bayur Lor. Cilamaya Kulon. Looking at some of the existing problems, researchers use the waterfall method in making an information system. Applications made in this study are based on android. To facilitate the mention of this application, namely Android-based LAGILEMAS (Public health center Digital Service).
\end{abstract}

Keywords: Public health center, Waterfall, Android Application

\title{
1. PENDAHULUAN
}

Penyelenggaraan pelayanan kesehatan untuk masyarakat ditingkat dasar di Indonesia adalah melalui Pusat Kesehatan Masyarakat (Puskesmas) yang merupakan unit organisasi fungsional. Peningkatan kualitas layanan kesehatan di Puskesmas dirasa semakin penting, hal ini dikarenakan masyarakat semakin selektif untuk mendapatkan pelayanan kesehatan yang berkualitas, mereka sebagai pengguna jasa tidak hanya membayar namun menuntut pelayanan yang baik dan berkualitas mulai di awal hingga akhir (Nurhayati, 2016). Puskesmas menjadi sebuah pelayanan pemerintah yang harus menyiapkan fasilitas kesehatan secara maksimal, selain dari sisi tenaga medis dan fasilitas kesehatan, puskesmas juga harus memiliki sistem informasi yang terintegrasi, contoh kecilnya adalah yang diterapkan dipuskemas karangploso kabupaten malang (Rahman et al., 2018).

Pusat Kesehatan Masyarakat atau sering disebut PUSKESMAS merupakan instansi pemerintah yang memiliki peran penting dalam upaya pelayanan kesehatan. Puskesmas di era revolusi industri 4.0 sudah seharusnya memiliki sebuah sistem informasi yang dapat menunjang pelayanan kesehatan berbasis teknologi dan informasi. Sistem informasi pada puskesmas memiliki kegiatan secara rutinitas yaitu antrian pasien, registrasi pasien, sampai rekam medis pasien (Sundari, 2016). Permasalahan yang dihadapi oleh puskesmas saat ini, khususnya pada puskesmas Bayur Lor kecamatan cilamaya kulon kabupaten karawang adalah proses pendataan pasien dari mulai pendaftaran pasien dan pengarsipan catatan medis pasien yang masih dilakukan secara manual, artinya semua proses masih ditulis pada tumpukan-tumpukan kertas dan di simpan pada rak-rak penyimpanan, sehingga ketika pihak 
Hal : $215-229$

puskesmas membutuhkan data-data pasien, laporan kunjungan, dan juga laporan data obatobatan yang sudah digunakan, perlu waktu yang cukup lama untuk mencari dimana data tersebut disimpan karena masih dalam pembukuan.

Konsep dasar sistem informasi adalah suatu sistem didalam suatu organisasi yang mempertemukan kebutuhan pengelolaan transaksi harian, mendukung operasi, bersifat manajerial, dan kegiatan strategi dari suatu organisasi dan menyediakan pihak luar tertentu dengan laporan-laporan yang dibutuhkan (Hutahaean, 2015). Sistem informasi merupakan hasil dari pengembangan teknologi yang menggabungkan antara sistem dan informasi. Dengan teknologi sistem informasi dapat meningkatkan efektifitas dan efisiensi dalam sebuah pekerjaan (Nurfitriana et al., 2020). Dari kedua literatur diatas dapat disimpulkan bahwa sistem informasi adalah sistem yang berjalan dengan memanfaatkan teknologi informasi untuk menghasilkan efektifitas dan efisiensi pekerjaan.

Teknologi informasi digital pada saat ini sudah menjadi kebutuhan pokok bagi para pelaku pengembang sistem informasi. Hal ini karena sistem informasi berbasis digital sangat memudahkan para pengguna dalam mengaksesnya. Sistem informasi berbasis digital atau sering disebut android merupakan sistem operasi berbasis linux yang dimodifikasi untuk perangkat (mobile device) yang terdiri dari sistem operasi, middleware, dan aplikasiaplikasi utama (Juhara, 2016). Android adalah sistem operasi berbasis linux yang dimodifikasi untuk perangkat bergerak (mobile device) yang terdiri dari sistem operrasi, middleware, dan aplikasi-aplikasi utama. Awalnya, Android dikembangkan oleh Android Inc (Susanti \& Aifan, 2019). Penggunaan android selama ini banyak digunakan untuk membuat sebuah aplikasi game. Seiring perkembangan zaman android juga dapat digunakan untuk pembuatan sebuah aplikasi layanan pemesanan ambulans pada tingkat puskesmas (Nasrullah et al., 2019) . Selain itu kehadiran android semakin melengkapi fasilitas kesehatan dengan sebuah aplikasi komunikasi puskesmas berbasis android (Anofrizen \& Elita, 2018). Pemanfaatan android sudah secara umum melapisi semua elemen yang ada. Baik dari dunia pendidikan, pemerintahan sampai dunia usaha (makro/mikro).

Berdasarkan pernyataan diatas, perkembangan dunia teknologi digital berbasis android dapat dikombinasikan kedalam peningkatan kualitas pelayanan kesehatan. Oleh karena pada kesempatan ini peneliti akan membuat aplikasi LAGILEMAS (Layanan Digital Puskesmas) Berbasis Android.

\section{TINJAUAN PUSTAKA}

Tinjauan pustaka pada penelitian ini adalah dengan menyertakan sumber-sumber penelitian terdahulu sebagai bahan pembaharuan penelitian.

Manajemen puskesmas sangatlah penting, hal ini dibutuhkan karena untuk menghindari beberapa permasalahan yang dapat terjadi pada proses registrasi pasien masih sering terjadi masalah bagaimana cara mengidentifikasi antara pasien lama dengan pasien baru. Sebagai solusi pemecahan masalah tersebut dibangunlah sebuah sistem informasi puskesmas berbasis website (Cahyanti \& Purnama, 2017).

Sistem informasi puskesmas berbasis website pernah dikembangkan dalam sebuah penelitian (Dewi et al., 2020), pada penelitianya bertujuan untuk memudahkan pihak puskesmas mengolah data pasien dan rekam medis pasien hingga menjadi sebuah laporan. yang cukup berat dalam mendapatkan informasi tentang pasiennya, kunjungan berobat pasien, rekam medis pasien dan juga data obat yang sudah digunakan oleh puskesmas 
tersebut. Selain masalah pendataan pasien dan pengarsipan catatan medis merupakan suatu hal penting yang perlu diperhatikan.

Pada literatur lain sistem informasi puskesmas berbasis web dikembangkan untuk Proses penggunaan kamar rawat inap yang selama ini berlangsung masih dilakukan secara manual, tidak menggunakan sistem sama sekali, sehingga para tenaga medis di pelayanan kesehatan yang berbeda kesulitan untuk mengetahui jumlah pasti kamar yang masih tersedia. Oleh karena itu, sistem informasi layanan kesehatan Puskesmas Keranggan dirancang dan dibangun sebagai upaya penyelesaian masalah di atas (Putri \& Kurniasari, 2020).

Dari ketiga tinjauan pustaka diatas peneliti semakin mendapatkan gambaran untuk melalukan penelitian di bidang kesehatan, khususnya pada tingkat puskesmas. Permasalahan yang sering muncul pada puskesmas meliputi data pendaftaran pasien, pendaftaran rekam medis, data obat, sampai pada proses pembuatan laporan. Untuk pembaharuan penelitian yang dilakukan saat ini yaitu: membangun Sistem Informasi Layanan Digital Puskesmas (LAGILEMAS) Berbasis Android. Keunggulan yang akan didapat pada penelitian ini tentunya adalah aplikasi sistem puskesmas dapat dinikmati pada mobile phone.

\section{METODE PENELITIAN}

Pada penelitian ini, untuk menunjang dan memperkuat hasil dari penelitian. Maka dilakukan beberapa metode penelitian yang meliputi:

\section{A. Metode Pengumpulan Data \& Observasi}

Pada metode pengumpulan data dan observasi peneliti lakukan dengan cara datang langsung ke puskesmas untuk mengetahui kondisi sebenarnya, selain itu juga peneliti melakukan wawancara dari masing-masing bagian terkait yang ada pada sistem puskesmas.

\section{B. Metode Pengembangan Sistem}

Pada metode pengembangan sistem menggunakan metode waterfall, metode waterfall merupakan model klasik yang memiliki sifat berurut dalam merancang software (Sholikhah et al., 2017). Model waterfall memiliki tahapan diantaranya :Analisa kebutuhan sistem, desain, pengkodean, dan pengujian.

1. Analisa kebutuhan sistem

Pada proses analisa kebutuhan sistem dilakukan dengan cara mempelajari kebutuhan sistem puskesmas bayur lor, kemudian dari hasil analisa kebutuhan sistem tersebut dibuatkan menu aplikasi yang ada pada sistem layanan kesehatan puskesmas. Untuk menu pada aplikasi layanan kesehatan antara lain: menu halaman utama, menu halaman registrasi peserta, menu halaman pendaftaran berobat, menu halaman dokter, menu halaman rujukan, menu halaman apoteker.

2. Desain

Pada proses desain dilakukan dengan cara membuatkan tampilan desain menggunakan diagram UML (Unified Modeling Languague). Diagram UML yang digunakan adalah use case diagram. Setelah proses pembuatan desain selesai, maka hasil diagram use case akan digunakan dalam perancangan aplikasi berbasis android. 
3. Pengkodean

Pada proses pengkodean dilakukan dengan cara megimplementasikan hasil desain menggunakan bahasa pemograman. Untuk bahasa pemograman yang digunakan dalam pembuatan aplikasi layanan kesehatan puskesmas yaitu bahasa pemograman PHP, Javascript. Untuk mempermudah lokasi ada penambahan Google Maps API yang berfungsi secara otomatis Google maps bisa di integrasikan kedalam Web atau aplikasi yang sedang buat.

4. Pengujian

Pada proses pengujian dilakukan dengan menggunakan pengujian secara black box testing. Proses pengujian ini diharapkan bisa menghilangkan kesalahan yang akan terjadi dan menjadikan sebuah parameter apakah aplikasi layanan kesehatan puskesmas dapat berjalan sesuai dengan kebutuhan sistem.

\section{HASIL DAN PEMBAHASAN}

Hasil dan pembahasan pada penelitian layanan kesehatan menggunakan metode waterfall adalah sebagai berikut:

\section{A. Analisa Kebutuhan Sistem}

Hasil dari analisan kebutuhan sistem layanan digital puskesmas (lagilemas) yaitu:

1. User atau Pasien

Kebutuhan sistem untuk user atau pasien antara lain:

- User atau pasien masuk kehalaman aplikasi utama lagilemas dapat melakukan registrasi untuk login.

- User atau pasien masuk kehalaman login untuk langsung melakukan pendaftaran berobat atau melihat riwayat, panduan, pilihan, kritik atau saran pelayanan pada puskesmas.

- User atau pasien masuk kehalaman pendaftaran berobat untuk melakukan pilihan berobat yang akan dipilih.

- User atau pasien masuk kehalaman riwayat dan melihat riwayat berobat yang sebelumnya telah dilakukan.

- User atau pasien masuk ke tampilan panduan, dihalaman tersebut pasien dapat membaca panduan pada pelayanan ataupun prosedur puskesmas yang sudah diterapkan.

- User atau pasien masuk kehalaman pilihan dapat melihat jadwal dokter dan visi misi pada puskesmas.

- User atau pasien masuk kehalaman kritik dan saran jika ada yang ingin disampaikan mengenai pelayanan maupun aplikasi tersebut.

- User atau pasien dapat melakukan logout jika pasien telah selesai melakukan login pendaftaran pada akun tersebut.

2. Admin Puskesmas

- Admin Puskesmas dapat masuk kehalaman login untuk masuk dan mengelola data pasien, laporan, jadwal dokter atau mantra, kritik dan saran, profile, data admin, dan data poli.

- Admin Puskesmas dapat mengelola data pasien baru ataupun pasien lama 
- Admin Puskesmas dapat membuat laporan dan mencetak laporan dengan mudah.

- Admin Puskesmas dapat mengelola jadwal dokter atau mantri jika ada perubahan.

- Admin Puskesmas dapat mengelola krtik dan saran yang telah diberikan pasien atau pengunjung dan membuat balasan nantinya.

- Admin Puskesmas dapat mengelola data poli dimana pasien yang berobat dapat mengetahui diagnosa yang diderita pasien tersebut.

3. Dokter

- Dokter dapat masuk kehalaman login untuk mengelola rekam medis, poli umum, poli gigi, poli KIA, poli lansia, sesuai dengan poli dokter tersebut.

- Dokter memeriksa pasien dan memberikan hasil diagnosa untuk rekam medis pasien.

- Poli umum dapat memeriksa pasien dalam semua jenis penyakit secara keseluruhan(umum).

- Poli gigi merupakan pelayanan yang memberiksa khusus pelayanan gigi dan mulut.

- Poli KIA (kesehatan ibu dan anak) memberikan kesehatan pelayanan ibu dan anak.

- Poli lansia melaksanakan pelayanan kesehatan kepada lansia yang meliputi: promotif, preventif, kuaritif, dan rehabilitative. Yang melayani pemeriksaaan tindakan dasar untuk lansia atau pasien yang berusia 60 tahun keatas.

4. Apoteker

- Apoteker dapat masuk kehalaman login untuk mengelola obat masuk, satuan obat, table obat masuk dan keluar, table satuan obat, dan data resep obat pasien.

- Apoteker dapat mendata obat masuk dan keluar pada aplikasi.

- Apoteker dapat memberikan satuan obat pada pasien yang sudah di periksa oleh dokter meliputi: pil, sirup, dan jenis lainnya.

- Apoteker dapat mengelola table obat yang masuk dan keluar untuk laporan.

5. Admin Rumah Sakit

- Admin Rumah Sakit dapat masuk kehalaman login untuk masuk dan mengelola rujukan pasien puskesmas kerumah sakit

- Admin Rumah Sakit memberikan kamar rawat inap 
Hal : $215-229$

\section{B. Desain}

Desain pada penelitian ini dibuat menggunakan diagram UML use case diagram. Ada 4 aktor yang berperan aktif pada sistem informasi layanan kesehatan puskesmas.

1. Use Case Diagram User Atau Pasien

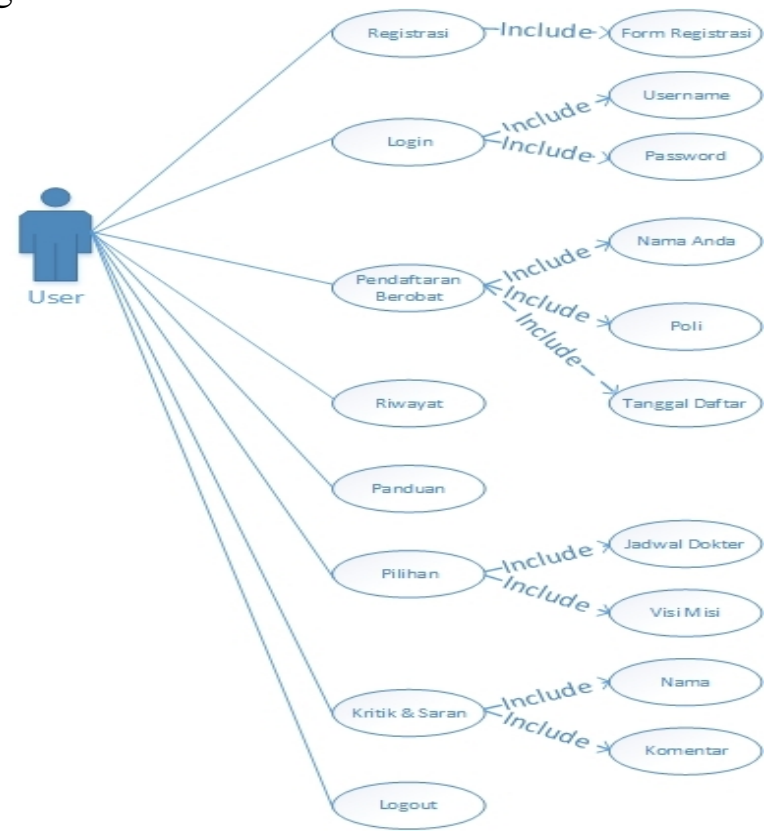

Gambar 1. Diagram Use Case User atau Pasien

Pada gambar 1. Diagram use case user atau pasien merupakan desain diagram UML yang menggambarkan bagaimana user atau pasien dapat mengakses menu registrasi yang berfungsi untuk user atau pasien melakukan registrasi sehingga user atau pasien dapat melakukan login kedalam sistem. Menu login berfungsi untuk user atau pasien yang sudah memiliki akses kedalam sistem. Menu pendaftaran berobat berfungsi untuk melakukan pendafataran berobat pasien melalui bagian administrasi, sebagai catatan pasien sudah melakukan registrasi akun melalui website. Menu riwayat berfungsi untuk melihat riwayat pasien yang telah berobat sebelumnya. Menu pilihan adalah menu untuk melihat jadwal dokter, dan untuk melihat visi misi, menu kritik \& saran berfungsi untuk memberikan kritik atau saran dari pasien kepada pelayanan puskesmas, dan menu logout berfungsi untuk keluar dari sistem. 
2. Use Case Diagram Admin Puskesmas

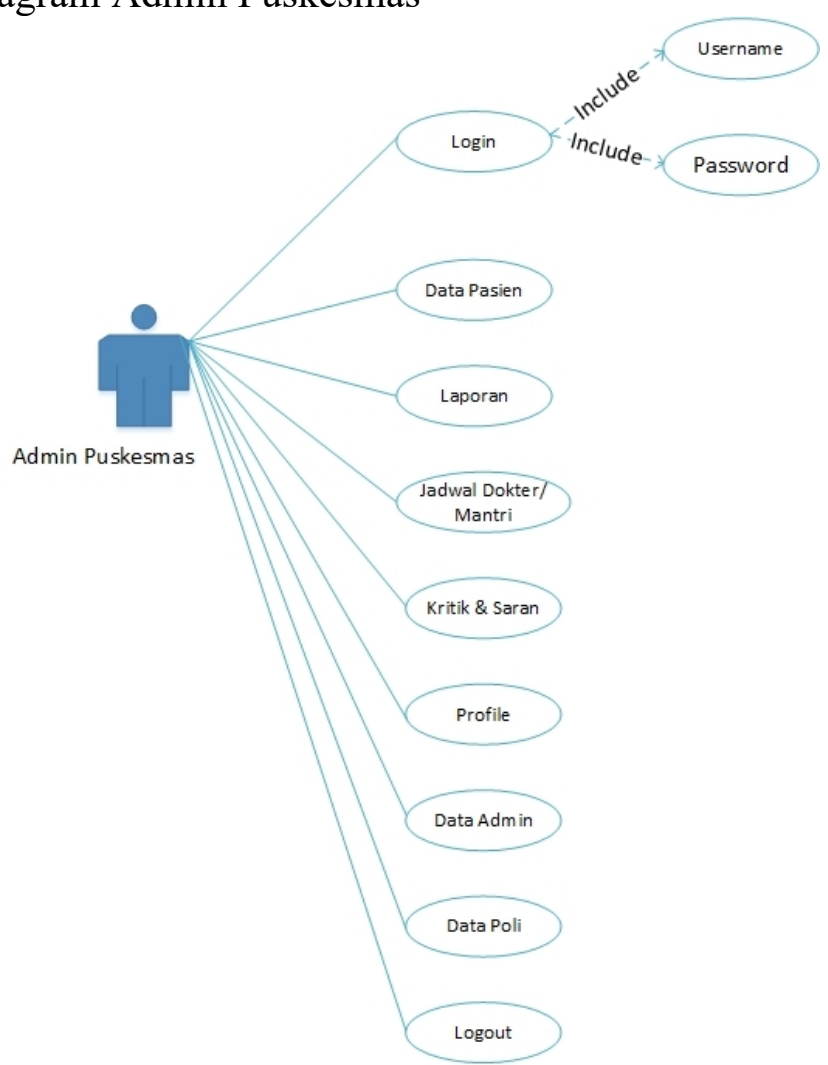

Gambar 2. Diagram Use Case Admin Puskesmas

Pada gambar 2. Diagram use case user admin puskesmas merupakan desain diagram UML yang menggambarkan bagaimana admin puskesmas dapat mengakses kedalam sistem. Menu login berfungsi agar admin puskemas dapat masuk kedalam sistem. Menu data pasien berfungsi untuk admin puskesmas mengelola data pasien. Menu laporan berfungsi untuk admin puskesmas melihat dan mencetak laporan keuangan. Menu jadwal dokter/mantri berfungsi untuk admin puskesmas mengelola jadwal dokter/mantri. Menu kritik \& saran berfungsi untuk admin puskesmas dalam memberikan kritik \& Saran terkait fasilitas yang ada pada puskesmas. Menu profile berfungsi untuk admin puskemas melihat dan merubah profile yang sudah ada. Menu data admin adalah menu yang berisi terkait data bagian administrasi. Menu data poli adalah menu yang berisi data poli yaitu poli Umum, Poli Gigi, Poli KIA-KB, Poli LANSIA. Menu logout berfungsi untuk admin puskesmas keluar dari sistem. 
Hal : $215-229$

3. Use Case Diagram Dokter

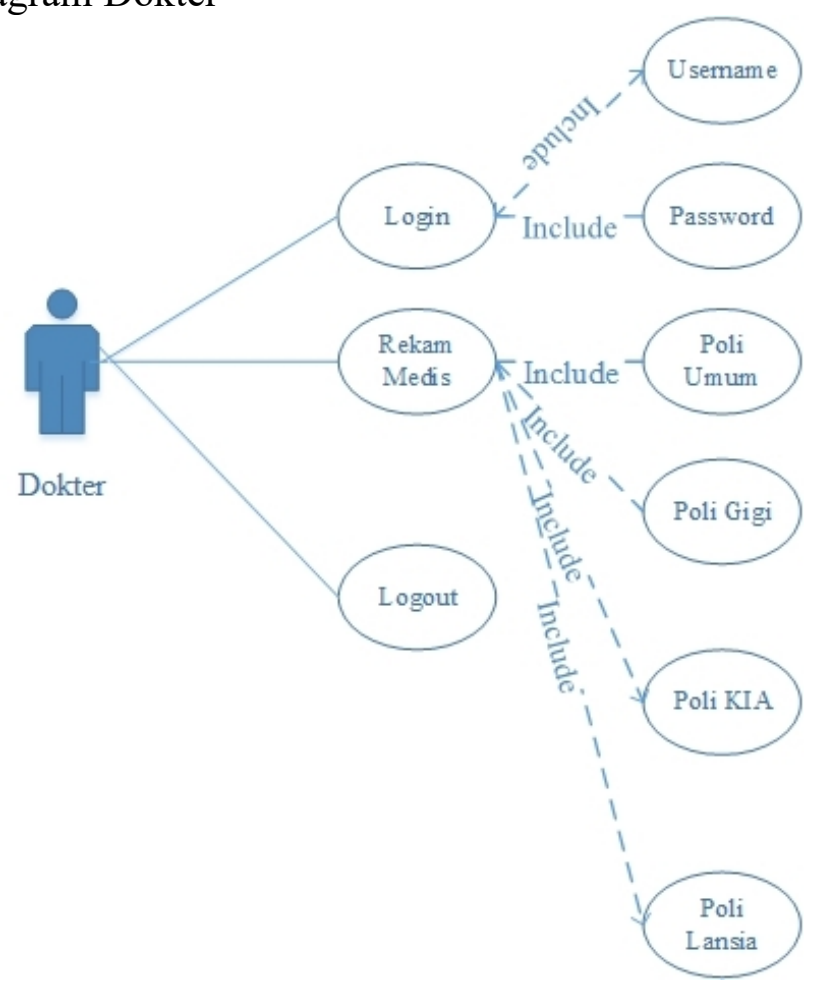

Gambar 3. Use Case Diagram Dokter

Pada gambar 3. Diagram use case user dokter merupakan desain diagram UML yang menggambarkan bagaimana dokter dapat mengakses kedalam sistem. Menu login adalah menu yang digunakan dokter untuk masuk kedalam sistem. Menu rekam medis adalah menu yang dimiliki oleh dokter untuk melakukan proses rekam medis. Menu logout adalah menu yang dapat digunakan oleh dokter untuk keluar dari sistem. 
Hal : $215-229$

4. Use Case Diagram Apoteker

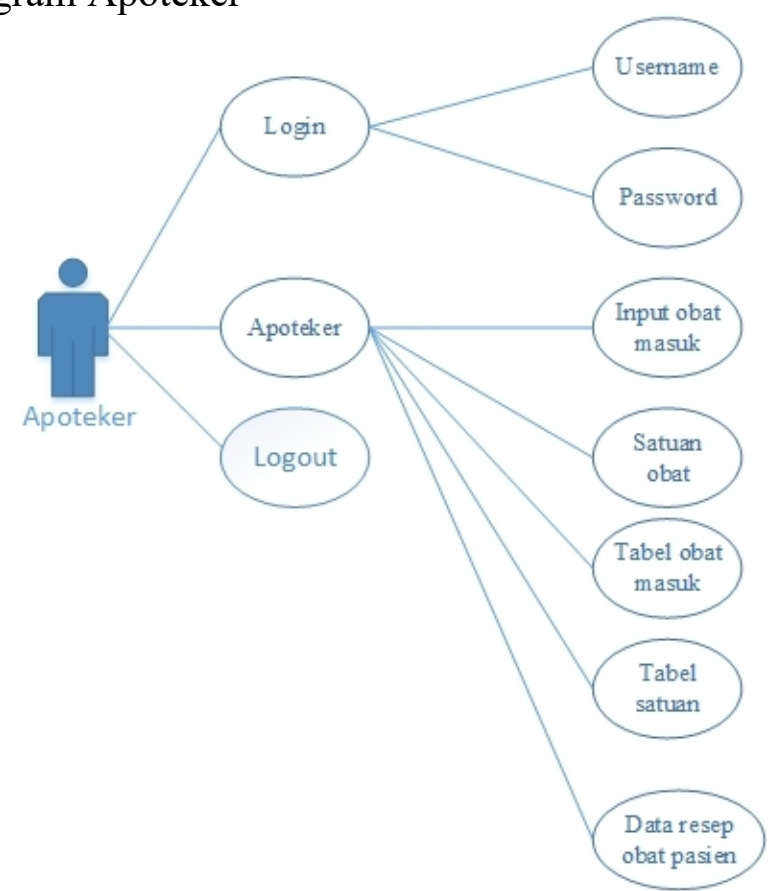

Gambar 4. Diagram Use Case Apoteker

Pada gambar 4. Diagram use case user apoteker merupakan desain diagram UML yang menggambarkan bagaimana apoteker dapat mengakses kedalam sistem. Menu login adalah menu yang digunakan apoteker untuk masuk kedalam sistem. Menu apoteker adalah menu yang digunakan oleh apoteker dalam mengelola obat. Menu logout adalah menu yang dapat digunakan oleh apoteker untuk keluar dari sistem.

5. Use Case Diagram Admin Rumah Sakit

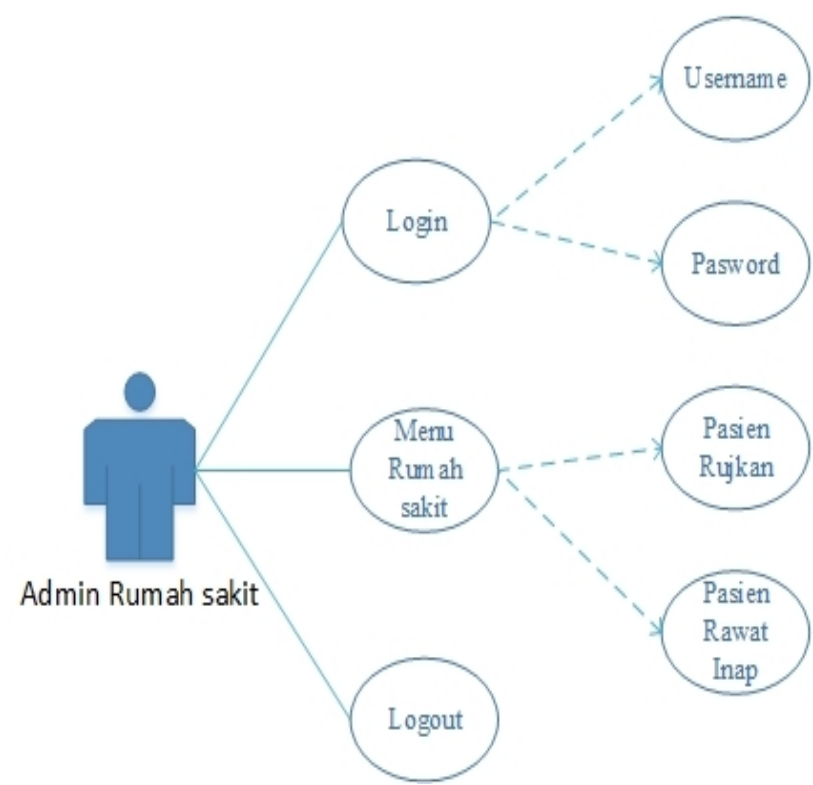

Gambar 5. Diagram Use Case Admin Rumah Sakit 
Hal : $215-229$

Pada gambar 5. Diagram use case user admin rumah sakit merupakan desain diagram UML yang menggambarkan bagaimana admin rumah sakit dapat mengakses kedalam sistem. Menu login adalah menu yang digunakan admin rumah sakit untuk masuk kedalam sistem. Menu rumah sakit adalah menu yang dapat digunakan oleh admin rumah sakit mendapatkan informasi dari puskesmas terkait pasien yang dirujuk ke rumah sakit. Menu logout adalah menu yang dapat digunakan oleh admin rumah sakit untuk keluar dari sistem.

\section{Implementasi Aplikasi Android}

1. Halaman Dashboard

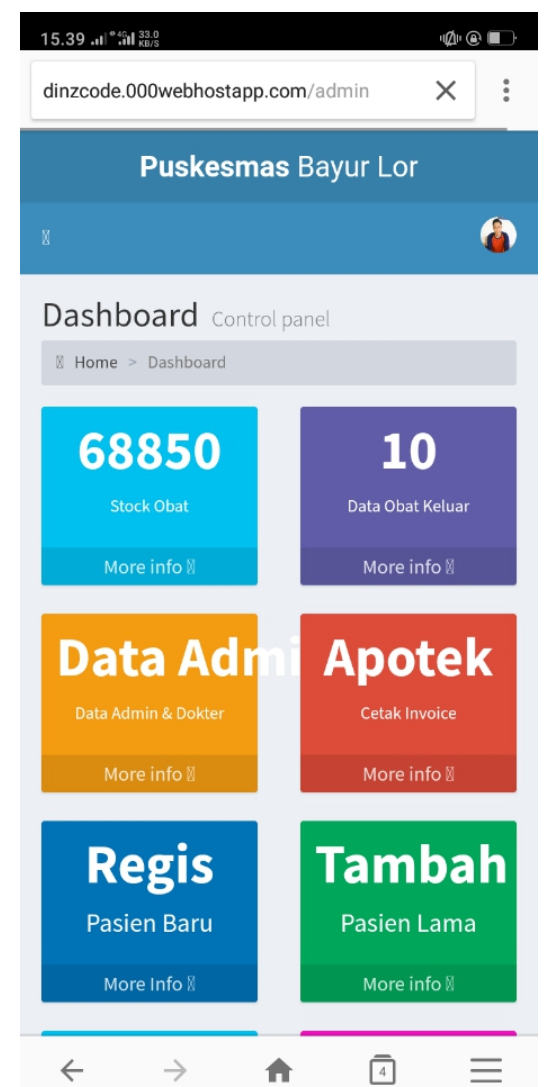

Gambar 6. Halaman Dashboard

Pada halaman dashoard terdapat beberapa menu yang memiliki informasi terbaru dari aplikasi layanan kesehatan puskesmas yaitu stok obat, data obat keluar, data admin dan dokter, apoteker registrasi, tambah pasien. 
Hal : $215-229$

2. Halaman Admin

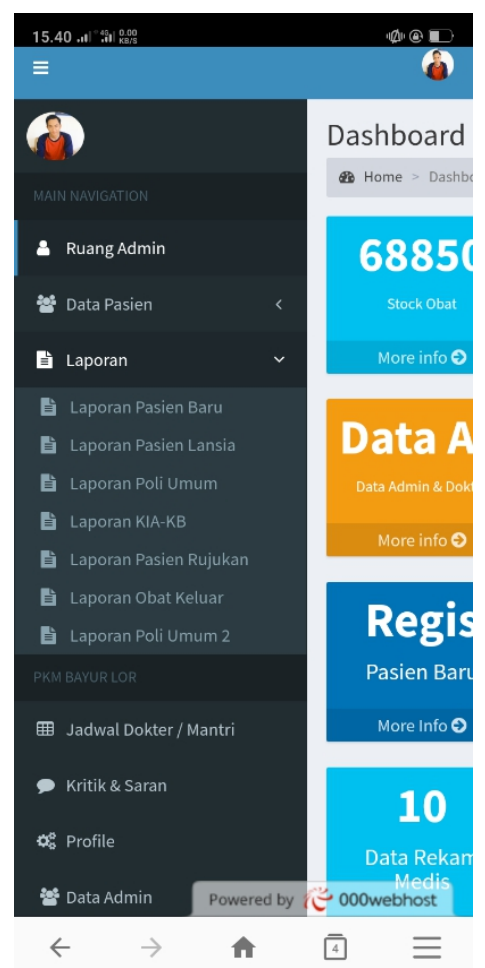

Gambar 7. Halaman Admin

Pada halaman admin terdapat menu ruang admin, data pasien, laporan, jadwal dokter, kritik \& Saran, Profile, Data Admin. Semua menu yang ada pada halaman admin digunakan untuk keperluan administrasi pelayanan kesehatan puskesmas.

3. Halaman Pendaftaran Baru
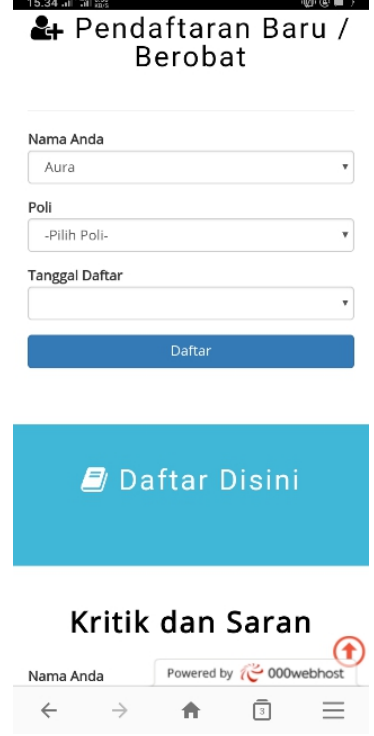

Gambar 8. Halaman Pendaftaran Baru/Berobat

Pada halaman pendaftaran baru digunakan untuk pasien yang mau berobat. Adapun data yang harus diisi adalah Nama, Poli, Tanggal Daftar. Jika 
$\mathrm{Hal}: 215-229$

berhasil mendaftar maka akan tampil no rekam medis. Jika pasien sudah pernah mendaftar maka langsung keluar no rekam medis, jika pasien belum pernah mendaftar maka pasien akan diarahkan kehalaman registrasi untuk mengisi biodata.

\section{Pengujian}

Pengujian yang dilakukan pada penelitian ini yaitu dengan menggunakan metode pengujian black box testing. Pengujian ini digunakan dengan harapan mengurangi kesalahan-kesalahan yang akan terjadi pada saat penggunaan aplikasi. Berikut ini beberapa pengujian yang dilakukan sebagai berikut :

1. Pengujian Halaman Admin

Tabel 1. Pengujian Halaman Admin

\begin{tabular}{|c|c|c|c|}
\hline $\begin{array}{l}\text { Kelas } \\
\text { Uji }\end{array}$ & Skenario Uji & $\begin{array}{l}\text { Hasil yang } \\
\text { diharapkan }\end{array}$ & Kesimpulan \\
\hline \multirow{6}{*}{$\begin{array}{l}\text { Halaman } \\
\text { Admin }\end{array}$} & $\begin{array}{ll}\text { Memilih } & \\
\text { Menu } & \text { Data } \\
\text { Pasien } & \\
\end{array}$ & $\begin{array}{l}\text { Menampilkan } \\
\text { Data Pasien }\end{array}$ & $\begin{array}{l}{[\sqrt{ }] \text { Berhasil }} \\
{[\quad] \text { Tidak Berhasil }}\end{array}$ \\
\hline & $\begin{array}{l}\text { Memilih } \\
\text { Menu } \\
\text { Laporan }\end{array}$ & $\begin{array}{l}\text { Menampilkan } \\
\text { Data Laporan }\end{array}$ & $\begin{array}{l}{[\sqrt{ }] \text { Berhasil }} \\
{[\quad] \text { Tidak Berhasil }}\end{array}$ \\
\hline & $\begin{array}{l}\text { Memilih } \\
\text { Menu Jadwal } \\
\text { Dokter }\end{array}$ & $\begin{array}{l}\text { Menampilkan } \\
\text { Jadwal Dokter }\end{array}$ & $\begin{array}{l}{[\sqrt{ }] \text { Berhasil }} \\
{[\quad] \text { Tidak Berhasil }}\end{array}$ \\
\hline & $\begin{array}{l}\text { Memilih } \\
\text { Menu Kritik } \\
\text { \& Saran }\end{array}$ & $\begin{array}{l}\text { Menampilkan } \\
\text { kolom kritik } \\
\text { \& Saran }\end{array}$ & $\begin{array}{l}{[\sqrt{ }] \text { Berhasil }} \\
{[\quad] \text { Tidak Berhasil }}\end{array}$ \\
\hline & $\begin{array}{l}\text { Memilih } \\
\text { Menu Profile }\end{array}$ & $\begin{array}{l}\text { Menampilkan } \\
\text { Profile yang } \\
\text { sedang login }\end{array}$ & $\begin{array}{l}{[\sqrt{ }] \text { Berhasil }} \\
{[\quad] \text { Tidak Berhasil }}\end{array}$ \\
\hline & $\begin{array}{l}\text { Memilih } \\
\text { Menu Data } \\
\text { Admin }\end{array}$ & $\begin{array}{l}\text { Menampilkan } \\
\text { data bagian } \\
\text { administrasi }\end{array}$ & $\begin{array}{l}{[\sqrt{ }] \text { Berhasil }} \\
{[\quad] \text { Tidak Berhasil }}\end{array}$ \\
\hline
\end{tabular}

2. Pengujian Halaman Pendaftaran Baru/Berobat

Table 2. Pengujian Halaman Pendaftaran Baru/Registrasi

\begin{tabular}{|c|c|c|c|}
\hline $\begin{array}{l}\text { Kelas } \\
\text { Uji }\end{array}$ & Skenario Uji & $\begin{array}{l}\text { Hasil yang } \\
\text { diharapkan }\end{array}$ & Kesimpulan \\
\hline $\begin{array}{l}\text { Halaman } \\
\text { Pendafta } \\
\text { ran } \\
\text { Baru/Ber } \\
\text { obat }\end{array}$ & $\begin{array}{l}\text { Mengisi } \\
\text { textbox nama, } \\
\text { Memilih } \\
\text { Option Botton } \\
\text { Poli, Mengisi } \\
\text { textbox } \\
\text { Tanggal } \\
\text { Daftar }\end{array}$ & $\begin{array}{l}\text { Textbox nama } \\
\text { Terisi, Option } \\
\text { Botton Poli } \\
\text { Terpilih, } \\
\text { textbox } \\
\text { tanggal terisi }\end{array}$ & $\begin{array}{l}\text { [ } \sqrt{ }] \text { Berhasil } \\
{[\quad] \text { Tidak Berhasil }}\end{array}$ \\
\hline & $\begin{array}{l}\text { Memilih } \\
\text { Tombol Daftar }\end{array}$ & $\begin{array}{l}\text { Tampil No } \\
\text { Rekam Medis }\end{array}$ & $\begin{array}{l}{[\sqrt{ }] \text { Berhasil }} \\
{[\quad] \text { Tidak Berhasil }}\end{array}$ \\
\hline
\end{tabular}


Dari hasil pengujian yang terdapat pada tabel 1 dan tabel 2 menghasilkan hasil yang sesuai dengan harapan. Pengujian Halaman admin dan Halaman Pendaftaran/Baru secara fungsional telah berjalan dengan baik.

\section{SIMPULAN}

Berdasarkan hasil penelitian Sistem Informasi Layanan Digital Puskesmas Berbasis Android maka dapat disimpulkan bahawa aplikasi layanan digital puskesmas berbasis android sangat membantu proses administrasi pada puskesmas bayur lor kec. Cilamaya kulon, kabupaten karawang, proses antrian peserta dapat berjalan dengan kondusif, peserta atau pasien datang sesuai jadwal dokter yang terdapat pada aplikasi, data obat terorganisir dengan baik, laporan pendapatan atau laporan keuangan dapat dilihat secara up to date.

\section{UCAPAN TERIMAKASIH}

Terima kasih kepada Universitas Bina Sarana Informatika PSDKU Karawang yang telah mendukung proses penelitian ini sampai selesai. Terima kasih kepada JTOS (Jurnal Teknologi dan Open Source) Universitas Kuantan Singingi yang telah menerbitkan karya penulis.

\section{DAFTAR PUSTAKA}

Anofrizen, A., \& Elita, F. (2018). Sistem Informasi Komunikasi Puskesmas Menggunakan Session Initiation Protocol Berbasis Android. Jurnal Ilmiah Rekayasa Dan Manajemen Sistem Informasi, 4(2), 194. https://doi.org/10.24014/rmsi.v4i2.5688

Cahyanti, A. N., \& Purnama, B. E. (2017). Pembangunan Sistem Informasi Manajemen Puskesmas Pakis Baru Nawangan. Speed Journal - Sentra Penelitian Engineering Dan Edukasi, 4(4), 17-21. https://doi.org/10.3112/SPEED.V4I4.893

Dewi, B. R., Rahajo, S., \& Adhitya, E. (2020). Perancangan Sistem Informasi Puskesmas Berbasis Web. Jurnal IKRA-ITH Informatika, 4(103), 12-19.

Hutahaean, J. (2015). Konsep sistem informasi. Deepublish.

Juhara, Z. P. (2016). Panduan Lengkap Pemrograman Android. Yogyakarta: Andi Yogyakarta.

Nasrullah, N., Zulkarnaen, M. F., \& Saleh, M. (2019). Aplikasi Berbasis Android Sebagai Layanan Pemesanan Ambulans Studi Kasus Puskesmas Aik Darek. Jurnal Manajemen Informatika Dan Sistem Informasi, 2(2), 47. https://doi.org/10.36595/misi.v2i2.103

Nurfitriana, E., Apriliah, W., Ferliyanti, H., Basri, H., \& Ratnawati. (2020). Implementasi Model Waterfall Dalam Sistem Informasi Akuntansi Piutang Jasa Penyewaan Kendaraan Pada Pt. Tricipta Swadaya Karawang. Jurnal Interkom, 15(1), 36-45. https://doi.org/10.35969/interkom.v15i1.69

Nurhayati, M. (2016). Peran Tenaga Medis dalam Pelayanan Kesehatan Kabupaten Kutai Barat. Llmu Administrasi Negara, 4(1), 2127-2140.

Putri, F. P., \& Kurniasari, F. (2020). Sistem Informasi Layanan Puskesmas Berbasis Web. Ultimatics, 11(2)(Jurnal Teknik Informatika), 89-93. https://doi.org/10.31937/ti.v11i2.1457 
Hal : $215-229$

Rahman, M. H., Tolle, H., \& Dewi, R. K. (2018). Pengembangan Sistem Informasi Pelayanan Ibu Hamil Pada Platform Android Berbasis Lokasi ( Studi Kasus : Puskesmas Karangploso Kabupaten Malang ). 2(11), 5784-5791.

Sholikhah, I., Sairan, M., \& Syamsiah, N. O. (2017). Aplikasi Pembelian Dan Penjualan Barang Dagang Pada CV Gemilang Muliatama Cikarang. Teknik Komputer AMIK BSI, III (1), 16-23.

Sundari, J. (2016). Sistem Informasi Pelayanan Puskesmas Berbasis Web. IJSE Indonesian Journal on Software Engineering, 2(1), 44-49.

Susanti, \& Aifan. (2019). Game Perakitan Komputer Berbasis Mobile Menggunakan Metode Finite State Machines (Fsm). Jurnal Teknologi Dan Open Source, 2(1), 24-33. https://doi.org/10.36378/jtos.v2i1.139 